\title{
ALISTAIR MUTCH
}

'To bring the Work to greater perfection': Systematising Governance in the Church of Scotland, 1696-1800

\section{ABSTRACT}

Following the confirmation of Presbyterian government in the Church of Scotland in 1690, a number of attempts were made to codify the governance practices that were to be followed in the various ruling bodies of the church. A review of these attempts indicates a distinctive approach to governance based on detailed record keeping and the monitoring of activities based on these records. While the church never managed to agree on a complete manual of procedure, a review of responses to the proposals suggests substantial conformance with their main precepts. Not only did these precepts contribute to the consolidation of the Presbyterian settlement of 1690 , they also provided a legalistic and systemic cast to organisational structures and practices. This then shaped a distinctive 'culture of organisation' which, in conjunction with other institutions such as education, provided to-hand resources for the widely noted Scottish competence in administration. A focus on administrative practices in their cultural and social context provides a basis for assessing claims to Scottish distinctiveness and influence.

In his study of English local identity, Keith Snell sets out to 'infuse cultural meaning into administrative history, to extend such history to show how it has many cultural and social causes and ramifications, and to demonstrate how those interacted with administrative 
reforms. ${ }^{1}$ Administrative history might appear something of a dry and tedious pursuit, especially if it is restricted to a simple recounting of legislative changes. However, seemingly mundane matters can both reflect wider cultural and social changes and also facilitate such changes. In his study of the origins of the early modern English state, Steve Hindle has drawn our attention to the importance of local practices, especially those involving the churchwarden, to the development of the 'social depth' of that state. ${ }^{2}$ Similarly, in his study of state formation in seventeenth-century Netherlands, Philip Gorski has pointed to bureaucratic innovations occasioned by Calvinism. ${ }^{3}$ In Scotland, a focus on the administrative history of the Church of Scotland as essayed in this article can do three things. It can complement work which points to the importance of the period between the Revolution settlement of 1690 and the Union of $1707 .{ }^{4}$ It can also show a distinctively Scottish focus on the creation of systems of governance which have longer-term implications. Finally, this focus on systemic governance in Scotland offers insights into the originary principles of other cultures influenced by Scottish practitioners, most notably the United States of America. These implications are developed further in the conclusions.

One important consequence of the distinctive Scottish focus on detailed record keeping is that the Church of Scotland has generated an extensive set of administrative records. These have been mined elsewhere to good effect to show how the new arrangements of the Reformed kirk took hold at local level in the seventeenth century, how the conduct of parishioners was subject to control through to the nineteenth century, and how poor relief was

\footnotetext{
${ }^{1}$ K. Snell, Parish and Belonging: Community, identity and welfare in England and Wales, 1700-1950 (Cambridge, 2006), 14.

${ }^{2}$ S. Hindle, The State and Social Change in Early Modern England 1550-1640 (Basingstoke, 2000).

${ }^{3}$ P. Gorski, The Disciplinary Revolution: Calvinism and the rise of the state in early modern Europe (Chicago, 2003).

${ }^{4}$ J. Stephen, Defending the Revolution: The Church of Scotland 1689-1716 (Farnham, 2013); C.A. Whatley, 'Reformed religion, regime change, Scottish Whigs and the struggle for the 'Soul' of Scotland, c.1688-c.1788', SHR 92 (2013) 66-99.
} 
centred on the kirk session. ${ }^{5}$ By contrast, the focus of this article is on the formation of the governance practices, centred on careful record keeping, that enabled these activities in the period of their mature operation, the eighteenth century. In particular, close attention is paid to the debates and evolution of the extensive guidance literature that informed local practice. The development of three important documents is examined: the Overtures Concerning the Discipline presented to the General Assembly of 1697; the Form of Process adopted by the same body in 1707; and the codification of practices by the ruling elder Walter Steuart of Pardovan in 1709, Collections and Observations Methodiz'd; Concerning the worship, discipline, and government of the Church of Scotland. ${ }^{6}$ These documents formed the backbone of the mature system of discipline and are worthy of consideration for the light that they cast both on national debates and on local practice.

The focus of the article is on the governance practices that enabled the public performance of rituals and discipline. These practices were implied by the beliefs of the church and led to the generation of extensive records in three primary ways. The practice most closely associated with the church was the public disciplining of sinners, involving public rites of humiliation and repentance. ${ }^{7}$ The founding documents of the church placed, 'the strict observance of Church discipline in accordance with what God's Word prescribes, whereby vice is suppressed and virtue promoted' at the heart of the church. ${ }^{8}$ It was necessary to exercise this discipline thoroughly and seriously, with full records of the evidence on

\footnotetext{
${ }^{5}$ M. Todd, The Culture of Protestantism in Early Modern Scotland (New Haven, 2002); A. Hanham, The Sinners of Cramond: The struggle to impose Godly behaviour on a Scottish community 1651-1851 (Edinburgh, 2005); R. Mitchison The Old Poor Law in Scotland: The experience of poverty, 1574-1845 (Edinburgh, 2000). ${ }^{6}$ Anon, Overtures Concerning the Discipline and Method of Proceeding in the Ecclesiastick Judicatories in the Church of Scotland: Humbly tendered to the consideration of the several presbytries, and to be by them prepared for the next, or some ensueing General Assembly [Overtures]; (Edinburgh, 1696) 'The form of process in the judicatories of the church of Scotland, with relation to scandal and censures', in Church Law Society, Acts of the General Assembly of the Church of Scotland 1638-1842 [Acts of the General Assembly] (Edinburgh 1843), 403-416 (1707); W. Steuart, Collections and Observations Methodiz'd; Concerning the worship, discipline, and government of the Church of Scotland (Edinburgh, 1709).

${ }^{7}$ D. MacCulloch, Reformation: Europe's house divided 1490-1700 (London 2004), 597.

${ }^{8}$ I. Hazlett, 'A new version of the Scots Confession, 1560', Theology in Scotland 17 (2010) 41-66 at 55
} 
which decisions were based. Accordingly, local church records, subject to review by presbyteries, were often thorough in this aspect. The exercise of this discipline, as opposed to its recording, is not the focus of this article, but is an inescapable background to it. A second stimulus for record keeping was the importance attached to the sacrament of communion. The desire to ensure that only the faithful and worthy were admitted to the communion table meant, Todd argues, that 'good record-keeping is a hallmark of Scottish communion seasons, with lists of those eligible and those who actually appeared at the table routinely compared to ensure that no one had communicated unworthily'. ${ }^{9}$ Finally, there was an early stress on the central role of the church in providing poor relief. This was to be done at the parish level, administered by the elders on behalf of a community of believers who should look after each other's material as well as spiritual welfare. ${ }^{10}$ At a very early stage an accounting system was laid down, with concomitant requirements for forms of record keeping which set the tone for the exercise of governance practices. These were practices which placed considerable emphasis on the written record and the use of such records to monitor the activities of both persons and bodies within a system of accountability.

This system of accountability is arguably of enduring importance in the formation of Scottish identity. It formed part of what Hall has called, in the context of the United States of America, a 'culture of organisation'. ${ }^{11}$ By culture of organisation is meant two, overlapping, concerns. One is the extent to which social groups have ideas about organising. Such ideas can be manifest in the practices that such groups engage in or they can be more explicitly laid out in the form of organisational blueprints. Secondly, social groups may hold organisation to be a value in its own right; on the other hand, they may value other aspects of social

\footnotetext{
${ }^{9}$ Todd, Culture of Protestantism, 77. See also A. Ryrie, The Origins of the Scottish Reformation (Manchester, 2006) and L.E. Schmidt, Holy Fairs: Scotland and the Making of American Revivalism (Grand Rapids, MI, 2001).

${ }^{10}$ J. Knox, The History of the Reformation of Religion in Scotland by John Knox; with which are included Knox's Confession and The Book of Discipline, revised and edited by C. Lennox (London, 1905), 394-5.

${ }^{11}$ P.D. Hall, The Organization of American Culture, 1700-1900: Private institutions, elites and the origins of American nationality (New York, 1984).
} 
interaction, such as spontaneity. In this article it is suggested that the Church of Scotland had a distinctive tradition of the formal explication of organising principles and practices in detailed textual form and that this tradition reflected a commitment to order in church matters. In short, the church took the words of the Scots Confession of 1560 (quoting Paul), that 'all things be done decently and in order., 12

What was also distinctive about the Scottish context were the repeated attempts to lay down blueprints for the operation of these governance practices. While this article considers some of the antecedents of these attempts, the main focus is on the relatively neglected documents that stemmed from the revolution settlement and which remain of importance in discussions of presbyterian polity down to the present. ${ }^{13}$ They form an important backdrop to any investigation of local practices, where the interest is in the extent to which the routines laid down at central level were actually put into practice. Further, however voluminous, it is difficult for such guides to procedure to cater for every eventuality, and practices often had to be elaborated when they are put into operation. Consideration of these factors follows an examination of the debates that surrounded the initial formulation. Here, the focus is on the textual analysis of the documents in the context of broader debates. Then the focus shifts to the reception and evolution of the documents at presbyterial level before consideration is paid to the impact on practice at the local level.

\section{Process}

Kirk observes that in the Scottish reformation, 'the new kirk was accorded that rare and exhilarating experience, denied to most churches, of determining its own programme and constitution'. ${ }^{14}$ Through a complex process, a series of hierarchical courts evolved by the 1590s. At local level the minister and elders formed the kirk session. It was responsible to the

\footnotetext{
${ }^{12}$ I. Hazlett, 'Scots Confession', 58.

${ }^{13}$ J. Weatherhead (ed.), The Constitution and Laws of the Church of Scotland (Edinburgh, 1997).

${ }^{14}$ J. Kirk, Patterns of Reform: Continuity and change in the reformation kirk (Edinburgh, 1989), xv.
} 
presbytery at local level, composed of all the ministers in the area and selected elders. In turn a number of presbyteries constituted synods, whose activities, through their registers, were inspected by the annual general assembly. However, this framework was to come under attack over the course of the following century from the attempts to reintroduce bishops. There were some attempts to return to the structure and functioning of the church, notably at the General Assembly of 1638 but, 'What put a stop to Our Worthy Fathers going on, in giving a Compleat Directory for the discipline of the Church, and the Methods to be Used in Ecclesiastick Judicatories in their proceedings, some yet alive may Remember' ${ }^{15}$

This observation comes from the introduction to Overtures Concerning the Discipline and Method of Proceeding in the Ecclesiastick Judicatories in the Church of Scotland. Prepared by private hands and printed in 1696 by the printer to the General Assembly, this work sought to take advantage of the confirmation of the presbyterian system of church governance in Scotland by William in 1690 to revive the project of a complete guide to the functioning of the several bodies of the church. ${ }^{16}$ The 1697 Assembly arranged for the Overtures to be sent to presbyteries, asking for their observations. ${ }^{17}$ Considering the scale of the work, the Assembly in the following year appointed a committee to consider revision. This committee consisted of the principals of Glasgow and Edinburgh Universities, six ministers and, of significance in the light of discussions below, Sir James Stewart, his Majesty's Advocate, Adam Cockburn of Ormiston, Lord Justice-Clerk, and Sir Colin Campbell of Aberuchle, one of the Senators of the College of Justice, as Ruling Elders. ${ }^{18}$ By 1703 this committee reported that they had carried out revisions and obtained comments from

\footnotetext{
${ }^{15}$ Overtures, ii.

${ }^{16}$ Act ratifying the Confession of Faith and settling presbyterian church government, 7 June 1690, Records of the Parliament of Scotland, 1690/4/43, http://www.rps.ac.uk/, accessed 9 Jun. 2014; J. Stephen, 'Defending the Revolution: the Church of Scotland and the Scottish Parliament, 1689-95', SHR 89 (2010) 19-55; A. Raffe, 'Presbyterianism, secularisation, and Scottish politics after the Revolution of 1688-1690', Historical Journal 53 (2010) 317-337.

${ }^{17}$ Acts of the General Assembly, 258-9 (1697).

${ }^{18}$ Acts of the General Assembly, 272-3 (1698).
} 
some presbyteries. They recommended a further revision to be carried out, adding a further two chapters to the work. This was to be done by a further committee drawn from members of the synods of Lothian, Glasgow and Fife. Their numbers still included legal representation with the Lord President of the Session, Sir Hugh Dalrymple, joining Stewart and Campbell. ${ }^{19}$ In the following year the Assembly 'taking into their consideration that all the former endeavours about the bringing the printed Overtures of Discipline to a period, have not had the desired effect' advised their committee as follows:

The Assembly considering that albeit the printed Overtures for Discipline be not so succinct as need were, yet that the same, as now amended, may be very useful, do, therefore, recommend to the Commission to cause again revise the said whole overtures, with the amendments, and cause reprint and transmit the same to the several Presbyteries. ${ }^{20}$

In their Acts the Assembly adhered to the project of producing a complete guide to process, noting that,

Seeing there are several things wanting in the overtures now printed, to make the same a complete Book of Discipline, Presbyteries are entreated to continue in adding and amending, and to send their thoughts there anent in writing to the Clerk of the General Assembly, in order to the perfecting of this work. ${ }^{21}$

The consideration of the Overtures disappears from view for several years, overtaken by the momentous events leading to the Treaty of Union. As well as confirming the place of the Church of Scotland and confirming its governance structure, the Union also encouraged the adoption by the Assembly of the Form of Process, an extract from the Overtures dealing with the processes to be followed by all the bodies of the church. ${ }^{22}$ This, together with the

\footnotetext{
${ }^{19}$ Acts of the General Assembly, 323-4 (1703).

${ }^{20}$ Acts of the General Assembly, 336 (1704).

${ }^{21}$ Acts of the General Assembly, 336 (1704).

${ }^{22}$ Acts of the General Assembly, 403-420 (1707).
} 
publication of Steuart's Collections in 1709 rather took the steam out of efforts to promulgate an approved book of governance.

Walter Steuart had a small estate at Pardovan outside Linlithgow and had been an exile in the Netherlands before returning with William of Orange's victorious army. ${ }^{23}$ Later a parliamentary commissioner for Linlithgow, he was to be an opponent of union. ${ }^{24} \mathrm{He}$ was an elder at Linlithgow, attending presbytery meetings, and was a correspondent of Robert Wodrow, the ecclesiastical historian. ${ }^{25}$ Also, as brother-in-law of John Strling, Principal of Glasgow University, he was well-connected to influential figures in the new presbyterian establishment. ${ }^{26}$ His self-imposed task was to collect together material from a variety of sources to act as a primer for those studying theology and a guide to ministers and elders. ${ }^{27}$ He sought to bring together material from manuscript and printed records of the church, including the Overtures. Accordingly, his Collections in many ways superseded any official manual, although attempts continued to get one approved.

In 1708 presbyteries were reminded to send in their observations about the larger project, and in the following year the Assembly repeated its injunction in more detail, drawing the attention of presbyteries to specific passages. ${ }^{28}$ In 1710 a further committee was appointed to revise the Overtures and present them to the following Assembly. ${ }^{29}$ However, perhaps because of the perturbations represented by Jacobitism, the Overtures once again disappear from view, to re-emerge for the last time in 1718. The Assembly of that year,

\footnotetext{
${ }^{23}$ G. Gardner, The Scottish Exile Community in the Netherlands, 1660-1690 (East Linton, 2004).

${ }^{24}$ D. Patrick, 'The Kirk, Parliament and the Union, 1706-7', SHR 87 (2008, Supplement) 94-115; J. Stephen, Scottish Presbyterians and the Act of Union 1707 (Edinburgh, 2007), 45.

${ }^{25}$ Edinburgh, National Records of Scotland [NRS], Records of the Church of Scotland, CH2/242/8, Presbytery of Linlithgow, 23 Dec. 1796; R. Wodrow, Analecta, or Materials for a History of Remarkable Providences, 4 vols (Edinburgh, 1842-3), i. 12, 18, 19.

${ }^{26}$ A. Skoczylas, Mr. Simson's Knotty Case: Divinity, politics, and due process in early eighteenth-century Scotland (Montreal, 2001).

${ }^{27}$ Steuart, Collections, xi.

${ }^{28}$ Acts of the General Assembly, 430 (1708), 438 (1709).

${ }^{29}$ Acts of the General Assembly, 449 (1710).
} 
considering the necessity of having a complete system of rules for the procedure of the judicatures of this Church in matters of discipline, and that the framing of this is one of the most proper works of the General Assemblies of this Church, from which they have been long diverted by other incidental things, and not having time now to overtake this necessary work,

once again requested the views of presbyteries. ${ }^{30}$

This was the last time the project of a complete book of governance was to be considered by the Assembly, and it would appear that the success of Steuart of Pardovan's collection may have rendered the project still born. However, the Form of Process remains, as does Steuart's work, a cornerstone of the polity of the modern Church of Scotland and has also influenced other Presbyterian churches. ${ }^{31}$ Accordingly, there is value in looking in a little more detail at the overtures of 1696 and 1704 and then Pardovan's Collections in order to see if we can discern what matters were of concern and what their implications might be for taken-for-granted practices of organising.

\section{Antecedents and contents}

Quite clearly, the evolution of the guidance considered here took place in a context of considerable strife. In particular, the efforts following 1689 took place against the backdrop of the struggle against Episcopalianism and the need to consolidate the Revolution

Settlement. Thus, there was a conscious harking back to elements of previous discussions, given the need to arm a new cadre of ministers. However, the focus of what follows is on retrieving the details of more mundane administrative practices which have received less

\footnotetext{
${ }^{30}$ Acts of the General Assembly, 524 (1718).

${ }^{31}$ Weatherhead, Constitution and Laws, 157. For influence in the USA see, for example, the recollections of a Presbyterian minister, Ashbel Green, in 1849: 'When I was preparing for the gospel ministry, I was directed to read the Scotch collections of Steuart of Pardovan, as a book of authority on the government and discipline of the Presbyterian Church': cited in C. Coldwell, 'The religious observance of Christmas and 'Holy Days' in American Presbyterianism', The Blue Banner 8 (1999), http://www.fpcr.org/blue_banner_articles/americanxmas.htm, accessed 9 Jun. 2014.
} 
attention in the face of more dramatic events. While they are clearly shaped by these events, it is arguable that such practices formed longer enduring features of presbyterian polity and were resources for that 'culture of organisation' which is our prime focus. In this discussion of the content of the various overtures which sought to lay the foundation for a comprehensive book of discipline, the focus in particular is on the keeping of written records and the involvement of officers beyond the circle of ministers.

The documents are of some considerable extent, and it is important to maintain a focus on the underlying principles of the system of discipline. Much of this is to be found in fragmentary fashion in the earlier decisions of the General Assembly, albeit acting under conditions which often prevented their desires from being put into practice. A concern with the written word is evident in the General Assembly of 1638, for example, which sought to base its forthright restatement of presbyterian polity on surviving registers. ${ }^{32}$ There is extensive discussion of the provenance of the registers and their history. In the conditions of the time it is not surprising that the Assembly concerned itself with larger issues than the precise form in which records were to be kept, but that such records already formed a key part of the system of discipline is attested by the concern shown by the Assembly of 1642 at the lack of synodial books supplied for review, making reference to an ordinance of the previous Assembly which indicates that the issue of reviews of registers was an ongoing concern. The Assembly reaffirmed 'that the Books of every Provincial Assembly shall be brought and produced to every General Assembly'. At the same meeting they requested,'That the clerk at least subscribe every book before it come to the Assembly, and that every act be noted on the margent, for a directory of expedition. ${ }^{33}$

This concern with the nature of the records as a basis for monitoring is to be found in subsequent assemblies, such as the injunction in 1646 that 'their Registers be written

\footnotetext{
${ }^{32}$ Acts of the General Assembly, 2-5 (1638).

${ }^{33}$ Acts of the General Assembly, 53, 64 (1642).
} 
formally, and in a good hand writing, with the severall Leafes or Pages thereof marked by ciphers according to their number. ${ }^{34}$ The place of such records in the broader system of discipline is reinforced by the act of 1649 dealing with parochial visitations, in which it is laid down that, 'At the visitation of each Congregation, let the Session book be well visited, and for that effect, let it be delivered to two or three Brethren seven or eight days before the visitation, that their report of it may be in readiness against the Day of Visitation'. ${ }^{35}$ These concerns can be seen at local level in the remarkable 'platform for ordering session books' issued by the synod of Aberdeen and engrossed in the session book of Inverurie in 1650. This runs to 27 articles which range from the format of records to the content of entries, down to the correct form of expression:

To abstain and amend basse and unseamlie expressions, and to labour to have things rightlie wordit - as for his partie, to say his whore, for Laick elder (which is popishe), to say ruling elder, and for, ane ruling elder was chosin, or, such a man was chosen ruling to attend the presbitrie and prowenciall assemble, to say such a man of our ruling elders was chosen to attend, \&c., for stooll of repentance say, place apoyntit for publick repentance and confession of $\sin ^{36}$

Such detailed instructions run to two paragraphs, but the gist of the platform is to put into practice the acts of the Assembly, ordering in the first article, for example, 'That there be ane weell bound book of good paper, paged throughout, keeping a fair equable margent for the compend of acts'. ${ }^{37}$ So it would seem clear that the framers of the General Overtures were seeking to systematise existing practice and to put this in what seemed to them a logical and comprehensive form.

\footnotetext{
${ }^{34}$ Acts of the General Assembly, 136 (1646).

${ }^{35}$ The acts of the General Assemblies of the Church of Scotland from the year 1638 to the year 1649 inclusive, printed in the year 1682 to which are now added the index of the unprinted acts of these Assemblies, and the acts of the General Assembly, 1690 (Edinburgh, 1691), 428.

${ }^{36} \mathrm{~J}$. Davidson, Inverurie and the Earldom of the Garioch: A topographical and historical account of the Garioch from the earliest times to the revolution settlement (Edinburgh, 1878), 314.

${ }^{37}$ Ibid., 313.
} 
The Overtures extended to sixty pages split into three chapters. The first was concerned with general directions which might apply to any court of the church, the second with matters specific to kirk sessions and the third with the operation of presbyteries. Each chapter was further subdivided into headed sections dealing with a particular aspect. Within each section were short, numbered paragraphs, perhaps following the model set by Stair's Institutions. ${ }^{38}$ There is the sense of the logical structuring of topics with a particular focus on the definition of process, although, as we will see, this did not prevent the breaking through of more idiosyncratic opinions. The concern with the written record runs throughout and is given prominence in the third section of the first chapter. In an echo of the practice noted above, the clerk is enjoined to maintain both a book of minutes and a 'fair register' into which decisions should be copied. The overtures lay down that

This Register is to be paged, and a large margaine; Whereon the title or subject of the Acts and Orders, are to be indexed, for the more speedy finding anything; As also there ought to be a fair Index, and the end of each Book, of all the contents, and that Alphabetical. ${ }^{39}$

They go on to advocate an archiving process, whereby every session should deliver its register to the presbytery every ten years and every presbytery to the synod every fifteen years, with the resulting collection of registers, together with that of the synod, to be placed in the nearest university library 'where they may be safely keeped from Accidents, for the future benefit of the Church'. ${ }^{40}$

\footnotetext{
${ }^{38}$ James, Viscount of Stair, The Institutions of the Laws of Scotland, edited by D. M. Walker (Edinburgh and Glasgow, 1981).

${ }^{39}$ Overtures, 5.

${ }^{40}$ Ibid., 5.
} 
Much of the first chapter is concerned with process and how meetings are to be conducted, often in terms which are redolent of later guides to chairing meetings. It is here that one can hear the experience of the writers breaking through, in injunctions such as

He would likewise prevent the Members, their making long Harangues (savouring of mens loving to shew their Parts) or deviating to matters alien from the present Affair; he would keep them closs to the business, and to use few Words to gain time; and he will be called sometimes to interrupt talkative Members. ${ }^{41}$

The personal nature of some of these statements, which constantly break through the otherwise distanced and formal tone of the Overtures, can be put into even greater relief if we contrast the original version with that put by the General Assembly of 1704 to the presbyteries. During this period, as we have seen, the original Overtures were given to a committee for further consideration and revision. One major alteration they made was the addition of new chapters on proceedings and methods in synods and the General Assembly. This had always been the aim of the original authors and the new version came with the explicit warning that as to the two last chapters, concerning Synods and General Assemblies, \&c., they were never before in print nor transmitted, and so the opinions of Presbyteries were not given thereupon; and besides were not so narrowly examined by the Committees as the other chapters were, so that it can only be looked upon as coming from a private hand. ${ }^{42}$

A close comparison between the two documents would indicate that $65 \%$ of the sections in the first three chapters of the 1696 document were carried forward either unchanged or in similar vein to the revised version. Twenty six per cent were either removed altogether or combined with other material, leaving the committee to make significant

\footnotetext{
${ }^{41}$ Overtures, 3.

42 'Overtures concerning discipline and method in ecclesiastical judicatories', in Acts of the General Assembly, 338 (1704).
} 
amendments to about $9 \%$ of the sections. They also added twenty eight new sections to this initial material. If we combine this with the new chapters which they provided, then $44 \%$ of the revised document was entirely new. As we have seen, much of this was to complete the original project, so the interest rests with what was removed or amended. ${ }^{43}$

Particular attention was paid to the section 'Of Proceedings in all Church judicatories and the members' Behaviour therein'. Here we can see the elimination of the experience that clearly animated the original writer with the substitution of the cooler language of a committee. So, for example, paragraph ten of the original which gives guidance to courts to think carefully about charges being brought lest they fall foul of 'the Passion, Imprudence, Malice, or Self-designs, or mistaken Zeal of the Informers or Delators' has no direct equivalent. ${ }^{44}$ By contrast, sections on the calling of witnesses (sections fourteen and eighteen in the 1704 document) are given far more elaboration, suggesting the influence of the lawyers on the committee. Other sections that underwent substantial revision were those on admission to communion and those on the licensing and ordination of ministers. Some of the changes thus simply reflected the passage of time, but others showed the impact of committee work. What appears to have been missing was any consideration of how their recommendations reflected practical experience, even though practices such as visitations had been undertaken in the intervening years. ${ }^{45}$ Infused with a millenarian spirit, they appeared to be relying on the force of their words to bring practices into being.

While much of the rest was substantially the same, some of the changes made, although small in detail, are perhaps significant in setting the tone of the broader system of

\footnotetext{
${ }^{43}$ There were two significant removals of entire sections from the original document. The revisers did not think that discussion of the role of the church beadle warranted its own section and they also removed a whole section on acts of transportation, or the removal of ministers from one parish to another. In some areas they radically curtailed the discussion, most notably in the section 'anent marriage'. Here the original authors had supplied eight paragraphs indicating in detail what the processes should be at local level, but the revisers, citing an Act of the General Assembly of 1699, replaced this with a single paragraph exhorting the session to bear in mind what had been laid down.

${ }^{44}$ Overtures, 11.

${ }^{45}$ Stephen, Defending the Revolution, 108.
} 
discipline that was being promulgated. So, while the original document suggests that the session was to look among masters and heads of families to select new elders, the 1704 revision contained the significant phrase in parentheses 'they being not menial servants', thus circumscribing the social ranks available to serve. ${ }^{46}$ Some of these more secular and material concerns also find their way into new provisions in the section on ordination to obtain an expert valuation of the manse and to oblige the heritors to provide an account of the stipend 'that there may be as little debate as possible afterwards about that affair'. ${ }^{47}$ Similar concerns can be seen in the addition of a question to be asked at Presbyterial visitations, 'If there be a magistrate in the parish for punishing vice? ${ }^{48}$

Regular visitation lay at the heart of the disciplinary system and received particular attention by the revisers. The original twelve suggested questions to be asked of the eldership about their minister grew to eighteen and the focus on recording decisions was important in these. So they were to be asked 'Does he keep sessional meetings frequently, and is he impartial in the exercise of discipline against offenders, and is the session's diligence thereanent recorded in a book? ${ }^{49}$ Of course, the visitors should have known the answer already, for a new paragraph had been added earlier in the section enjoining that 'The session registers are to be produced to the Presbytery before the visitation, and given to some brethren to be revised, and they to report at the visitation'. ${ }^{50}$ This focus on monitoring activities through the careful keeping of records also runs through the completely new sections dealing with the activities of the synods and General Assembly. Thus each synod was to have a committee of four to five ministers and one or two elders to review ('revise') the books of presbyteries (with the proviso that they should not examine their own presbytery) and to prepare a report for the full synod. In turn, the books of each synod were to

\footnotetext{
${ }^{46}$ Acts of the General Assembly, 342 (1704).

${ }^{47}$ Acts of the General Assembly, 339 (1704).

${ }^{48}$ Acts of the General Assembly, 358 (1704).

${ }^{49}$ Ibid.

${ }^{50}$ Acts of the General Assembly, 358 (1704).
} 
be reviewed by a committee of the General Assembly, members being enjoined to follow the same process as synods but to 'to be more cautious as to what they bring publicly before the Assembly of their animadversions; imprudent publishing whereof, in any thing which may be otherwise remedied, being always prejudicial to the Church' ${ }^{51}$ The importance of written records can be seen in the continued recommendation about the archiving of registers to which was added

And that the Church may not want the present benefit of them, let doubles be taken, collated, and attested, whereof one to be sent to the university as aforesaid, and the other to be kept in the Clerk of the judicatory's hands. But it is to be considered upon whose expenses this is to be done. ${ }^{52}$

In summary, by 1704 the church had produced a significant codification of practice which laid particular stress on systematic forms of recording and monitoring conduct. However, emerging material concerns are suggestive that the 1704 revision was far from the final word. ${ }^{53}$ That there were elements of church practice that were still not covered will be seen in the examination below of aspects of practice in the localities. The original version was relatively silent about the importance of accounting, something which was of concern to the church's founders, anxious as they were to prevent church funds from expropriation by secular hands. Not surprisingly, then, the revisers added a new paragraph to the end of the section on privy censures which suggested that, 'Here also the kirk-treasurer's accounts may be taken in. ${ }^{54}$ The recommendation was that privy censures should be undertaken twice a year, suggesting the origins of the half-yearly accounting which was a feature of much local practice. Sessions were enjoined to produce their poor's box during visitations, but there is

\footnotetext{
${ }^{51}$ Acts of the General Assembly, 370 (1704).

${ }^{52}$ Acts of the General Assembly, 340 (1704).

${ }^{53}$ The practicality of this recommendation was a concern for discussion by Ayr presbytery: NRS, CH2/532/3, Presbytery of Ayr, 8 Mar. 1709.

${ }^{54}$ Acts of the General Assembly, 348 (1704). 'Privy censures' were where each member of a court removed himself from a meeting in turn and the remaining members discussed his conduct during the previous period.
} 
nothing about the production or format of accounts. These omissions can be seen when we examine practice, but first it is prudent to examine the fate of the Overtures in contrast to the Form of Process of 1707 and Steuart's Observations.

\section{The contribution of Steuart of Pardovan}

In 1709 the General Assembly adopted a Form of Process, extracted and developed from material contained in the Overtures which was to govern how church courts were to operate. ${ }^{55}$ An initial question, therefore, is the relation of the Form of Process to the revised Overtures of 1704. The Form of Process contained nine chapters, six of which carried titles almost identical to the 1704 Overtures. The Form of Process did not adopt the numbered paragraphs of the Overtures, so it is not so easy to carry out a detailed comparison, but some passages are identical in wording. ${ }^{56}$ There is a re-ordering and amplification of material, but the substantive changes are those which were needed to extract the elements of process from their original context. Thus, there is a new introductory section outlining the overall system of courts, and a chapter which pulls together the various injunctions about witnesses and evidence. The other major addition was a final chapter 'concerning the order of proceeding to absolution'. This was a document, then, the major purpose of which was to clarify the role of church courts acting as judicial bodies, with the removal of the consideration of the broader system of discipline. So, the presbyterial visitation, for example, plays no role in the Form of Process. The Form of Process, approved in 1707, continued to be referred to in texts regulating the affairs of the church but, as have seen, despite the urgings of several Assemblies, the larger overtures were never formally adopted. ${ }^{57}$ What took their place was Steuart's Collections.

\footnotetext{
${ }^{55}$ Acts of the General Assembly, 403-416 (1709).

${ }^{56}$ Such as that which dealt with drunkards: Steuart, Collections, 244-5.

${ }^{57}$ Weatherhead, Constitution, 157.
} 
In his endeavour Steuart explicitly referred to the 'Overtures concerning Discipline, Transmitted by them to Presbyteries' as of importance in his endeavours, but he also drew on the experience of other reformed churches, notably the French. ${ }^{58} \mathrm{He}$ also added references to the civil law 'which I hope the Reader will not find Unuseful or Impertinent', particularly from Stair's Institutions, which are referred to eleven times, with some further references to George Mackenzie, Lord Advocate from 1677 to 1686 and author of the first text on Scottish criminal law in $1678 .{ }^{60}$ But much of the book seems also to have drawn upon Steuart's own experience and to reflect, in particular, his conservatism. ${ }^{61}$ The work is split into four books. The first deals with the governance of the church, the second gives guidance on the nature of worship, the third details the nature of sins and scandals and the fourth suggests how such sins and scandals are to be disciplined. For the purpose of the present discussion, the main focus will be on the first book and, within this, on the presbyterial visitation. This is because this book bears the greatest relation to those portions of the Overtures that were left over after the sections on process had been filleted out. While the chapter on parochial visitations by the presbytery in Steuart has only ten sections, in contrast to the twenty two in the 1704 overtures, this is not because the discussion is shortened. Instead, many of the original questions are combined, and the logic and structure of the chapters is identical. Indeed, some text, such as that on the church officers, is also identical in both texts. The key difference between the two texts lies in the attention given to the questions to be asked about the minister and session. In both texts these questions lie at the heart of the visitation, but whereas the text recommended to the General Assembly contained

\footnotetext{
${ }^{58}$ Steuart, Collections, iv. See also J. Macgregor, The Scottish Presbyterian Polity: A study of its origins in the sixteenth century (Edinburgh, 1926).

${ }^{59}$ Steuart, Collections, iv.

${ }^{60}$ Steuart, Collections, 49, 87, 145, 169, 173, 179, 151, 246, 271, 276. This connection with legal writers is made explicit in a comment about Steuart's work in a later collection of Church of Scotland laws: 'it has accordingly been deemed a standard authority and guide in the church, as much as the Commentaries of any Institutional writer on the municipal law'. A. Peterkin, A Compendium of the Laws of the Church of Scotland (Edinburgh, 1840), 569. For MacKenzie, see J.D. Ford, Law and Opinion in Scotland during the Seventeenth Century (Oxford, 2007).

${ }^{61}$ Steuart, Collections, 103.
} 
nineteen questions directed at the conduct of the minister, Steuart had only eight, although these were expanded at considerable length. Thus, while the 1704 questions use 428 words, Steuart extends to over one thousand words. A flavour of his approach can be seen in the following extract from the first question:

Hath your Minister a Gospel Walk and Conversation before the People? And doth he keep family worship? And is he own who Rules well his own House? Is he a Haunter of Ale-houses and Taverns? Is he a Dancer, Carder or Dicer? Is he Proud or Vainglorious? Is he Greedy, or Wordly, or an Usurer? Is he Contentious, a Brawler, Fighter or Striker? Is he a Swearer of small or minced Oaths? Useth he to say, Before God it is so; or in his common Conference, I protest, or, I protest before God? Or says he, Lord, what is that? All of which are more than Yea or Nay? Is he a filthie Speaker or Jester? Bears he familiar Companie with Disaffected, Prophane or Scandalous Persons? Is he Dissolute, Prodigal, Light or Loose in his Carriage, Apparel, or Words? How spends he the Sabbath after Sermon? Saw ye him ever drink Healths? ${ }^{62}$ This opportunity to expound on the ills that evidently Steuart saw as threatening to ensnare ministers can also be seen, if to a lesser degree, in the questions to be asked about the conduct of the session. Here he uses 372 words to frame his eight questions, in contrast to the 187 words that the 1704 committee used for their eleven questions. By contrast, the passages on questions about the congregation are nearly identical in both.

One gets a sense here of the perspective of an activist, a pious ruling elder, concerned to maintain a tradition of discipline over ministers. It is interesting to note that one element which is removed from the discussion of the requirements of the visitation is the need to inspect the poor's box, and there is a sense that Steuart is seeking to return the focus to a more religious one. So, for example, his passage on the selection of elders does not repeat the

\footnotetext{
${ }^{62}$ Steuart, Collections, 60.
} 
exclusion on 'menial servants' that we saw added by the 1704 committee. Similarly, in an observation of seating he suggests that it would be best if 'Church Members would take their seats in the Church without respect of their Civil Character, as they do at the Lord's Table. ${ }^{63}$

That Pardovan was aware of important local practices in a way that was not evident in the previous Overtures is his recognition of the importance of the communion token something absent in the earlier works. He calls this, variously, the 'parish lead ticket', token or warrant, but, when coupled with his discussion about the need for lists of those eligible for entry to communion, this does suggest the importance of this practice. ${ }^{64}$ Steuart is at one, however, with the Overtures in stressing the importance of the recording of decisions. He offers extensive discussion of the need for revision of registers at different levels in the church and guidance which extends to the full detail that we noted being advocated in Inverurie in 1650. So, for example,

All Sentences and Acts are to be filled up in the Records, as all other things should be, according to the Priority of their being Voted or agreed unto, and that although no Extract hath been, or perhaps ever may be called for. And when any thing is omitted in the Body of a Record, it may be written on the Margine, which the Moderator and Clerk must Subscribe again. When any thing is Delete, let it be marked Delete on the Margine, and Subscribed as the other, counting the Lines or Words blotted out. ${ }^{65}$

By 1710 the church had an extensive body of work dealing with its governance, laying down the procedures and practices to be followed. It had an officially approved form of process to be followed in all its bodies and a substantial procedure manual, albeit one which had not been formally approved by the General Assembly. As we have seen, attempts to get such formal approval stumbled on until 1718. We might suggest that a combination of the widespread use of Steuart's text and other more pressing problems, notably patronage,

\footnotetext{
${ }^{63}$ Steuart, Collections, 176.

${ }^{64}$ Steuart, Collections, 138.

${ }^{65}$ Steuart, Collections, 94.
} 
drew attention away from completion of the project. ${ }^{66}$ However, simply the existence of this body of work is in itself of significance, not only in consolidating the Revolution settlement, but also in framing a distinctively Scottish approach to church governance. However, this is to tell us nothing of the reception of these various approaches, for predictably there can be a substantial gap between central pronouncements and practice on the ground. Accordingly, the next section offers a brief consideration of the unfolding practice at parish and presbytery level.

\section{Governance in practice}

Pardovan's view was conditioned by his location in an area where the institutional structures were relatively well established, something very different from the position elsewhere in Scotland. The Assembly spent much of its time considering the problems of the church north of the Tay, where Episcopalianism remained strong and the institutional structure of Presbyterianism absent or weak. Thus until 1706 the presbyteries of Turriff, Alford and Fordyce in Aberdeenshire were united, as were those of Deer, Ellon and the Garioch. ${ }^{67}$ Such bodies had little time to spend considering the niceties of procedure when they were faced with Episcopalian ministers who clung on to their churches. Further south, presbyteries also had pressing concerns in the earlier years that may have diverted their attention away from procedural details. Nevertheless, an examination of a sample of presbyterial records south of the Tay over the period 1696 - 1720 indicates a move towards detailed grappling with administrative and procedural issues. ${ }^{68}$ What this process indicates is the frustratingly slow

\footnotetext{
${ }^{66}$ In the Lothian parish of Gladsmuir in 1786 items passed on to a new treasurer included a copy of 'Pardovan's Collections': NRS, CH2/169/3/1, Gladsmuir Session Minutes 1775-1804, 3 Apr. 1786, 119.

${ }^{67}$ I. Simpson, Education in Aberdeenshire before 1872 (London, 1947), 19.

${ }^{68}$ The selection of presbyteries was conditioned by access to records held by the National Records of Scotland and focused on lowland presbyteries with some record of involvement in broader church affairs. The records of Edinburgh presbytery are unfortunately missing for the earlier period. The presbytery records examined were Ayr (CH2/532), Dunfermline (CH2/105), Edinburgh (CH2/121), Haddington (CH2/185), Hamilton (CH2/393), Kirkcaldy (CH2/224), Lanark (CH2/234) and Linlithgow (CH2/242).
} 
pace of change, given a system which depended on presbyteries having both the time and the inclination to respond to the urgings of the Assembly. Another qualifier is that where there was discussion of the Overtures, the decisions were not always recorded in the minutes. So, for example, Linlithgow presbytery recorded in 1697 that 'the Brethren had corrected their Animadversions on ye Book of Overtures for Church discipline and given them in to ye Commission of the General Assembly', but offers no further details. ${ }^{69}$ Nevertheless, even given these qualifications, three broad phases in the responses can be observed over time.

Phase one is the initial reaction to the Overtures. Yet, of seven presbyteries no evidence of discussion can be found in four. The minutes did record discussions in Ayr, Lanark and Linlithgow, but it was only in Linlithgow that a series of meetings were held to discuss the response which was eventually submitted, and in Linlithgow, a committee was appointed to discuss the form of process that formed a central part of the second phase. ${ }^{70}$ This phase, in turn, was concerned with responses to the revised proposals of 1704. Perhaps here the looming shadow of Union, with its need to secure the distinctive position of the church concentrated the mind, for there was now much more discussion. Linlithgow's committee, for example, offered detailed suggested amendments to specific passages of the proposals. ${ }^{71}$ All the presbyteries bar Hamilton (which was more concerned with the nature of the Union treaty) recorded detailed discussions. In Edinburgh, for example, the minutes recorded that on 5 February 1707 the 'third and fourth Chapters being read in their presence and discoursed upon, one paragraph after another, and several amendments made thereupon, the same were written on the margin of the said Overtures'. ${ }^{72}$

\footnotetext{
${ }^{69}$ NRS, CH2/242/8, Presbytery of Linlithgow, 17 Nov. 1697.

${ }^{70}$ NRS, CH2/242/8, Presbytery of Linlithgow, 8, 29 Sep., 20 Oct., 17 Nov. 1697; CH2/532/2, Presbytery of Ayr, 15 Sep., 19 Oct., 17 Nov. 1697; CH2/234/3, Presbytery of Lanark 20 Oct. 1697. This does tend to confirm the place of Linlithgow, perhaps reflecting the interests of Steuart in pressing the consideration of detailed rules of procedure.

${ }^{71}$ NRS, CH2/242/9, Presbytery of Linlithgow, 13, 27 Mar. 1706.

${ }^{72}$ NRS, CH2/121/6, Presbytery of Edinburgh. 5 Feb. 1707. Other discussions are recorded at 25 Sep., 11, 25 Dec. 1706; 15 Jan., 19 Feb., 5, 19 Mar., 2 Apr. 1707.
} 
The third phase was that which followed Union, when the focus which both the debates over Union and the Form of Process gave were replaced by disagreements which, in turn, contributed to the demise of the detailed overtures and their replacement by Steuart's guidance. This would appear to have been the case in Hamilton: having purchased 'Twenty copies of a book upon Church Discipline published by the Laird of Pardovan' to be distributed to their members, the Hamilton presbytery then failed to record any further responses. ${ }^{73}$ Lanark and Ayr also lacked any recorded consideration and Linlithgow, having paid so much attention to earlier versions, simply recommended that the Assembly 'remit them again to the several presbyteries of the Church'. ${ }^{74}$ There was, however, detailed discussion of the 1718 version in Haddington, Edinburgh, Dunfermline and Kirkcaldy, with the last three recording detailed suggested amendments. It is perhaps the tenor of Dunfermline's responses that suggest why the initiative eventually ran into the sand. The 1704 Overtures had been entangled with a subsequent overture which sought to establish 'general' sessions (bodies which sat over parish sessions) in large urban areas, and the presbytery of Dunfermline was particularly exercised by such suggestions. ${ }^{75}$ "They judge the Divine Warrant', they recorded, 'for parochial particular Sessions should be more expressly owned and affirmed' ${ }^{76}$ This was related to their concerns about roles being given to those who were not elders attached to particular congregations in church bodies. The force of their opposition was such that they instructed their commissioners to oppose the proposals being passed into Acts by the very venerable Assembly as much as they can, and if needs be to [exert] themselves by a public dissent and Protestation that this Presbytery

\footnotetext{
${ }^{73}$ NRS, CH2/393/2, Presbytery of Hamilton, 26 Jul. 1709.

${ }^{74}$ NRS, CH2/242/11, Presbytery of Linlithgow, 13 Apr. 1720.

75 J. Clark, Just and Sober Remarks on some Parts and Passages of the Overtures Concerning Kirk-Sessions, \&c (Glasgow, 1720).

${ }^{76}$ NRS, CH2/105/5, Presbytery of Dunfermline, 26 Apr. 1721.
} 
may be no ways accessory to Acts that appear contrary to the Scripture model of Church Government and destructive to this Church. ${ }^{77}$

This entanglement of the administrative rules with emerging fault lines in the church suggest why, after the Form of Process was agreed and Steuart's handbook formed a ready resource, attempts to produce a nationally approved handbook of procedure ultimately foundered.

However, what the presbyterial minutes also indicate is the degree to which the broad thrust of the proposals were actually being put into practice. They record, often in considerable detail, the outcome of parochial visitations. In 1706, for example, the visitation of Kirk Newton by the presbytery of Edinburgh was recorded over four pages, following the format laid down in the Overtures. ${ }^{78}$ Part of the reason for the detail was the investigation of allegations of financial irregularities, but similar detail is to be found in other registers. In 1707 Linlithgow also used four pages to record the outcomes of a presbyterial visitation at Kirkliston. On this occasion there were nine specific recommendations about the content and form of the session's register, ranging from the injunction, 'that the whole Elders names present at every Sederunt be marked and that absents be also marked and their excuses called for at the next meeting of the Session,' to, 'that they revise their Treasurers Accompts, Charges and Discharges and Balances the same exactly and that they record the same in their Register'. ${ }^{79}$ Session registers similarly bear the marks of presbyterial revision. It would be fair to argue that this regime relaxes over the course of the century and that practice was never by any means uniform. As late as 1790 , for example, the synod of Aberdeen was recording of the registers of the presbytery of Fordyce, that they were 'much too long in being filled up \& visited so that many things in them the Present Members cannot probably give any account of. Find a great want of the Record, from May $3^{\text {rd }} 1769$ to July 31, 1776.

\footnotetext{
${ }^{77}$ Ibid.

${ }^{78}$ NRS, CH2/121/6, Presbytery of Edinburgh, 10 Apr. 1706.

${ }^{79}$ NRS, CH2/242/9, Presbytery of Linlithgow, 25 Jun. 1707.
} 
Find many inaccuracies \& ill spelling. ${ }^{, 80}$ However, practice in this synod, for so long a stronghold of Episcopalianism, indicates that over the course of the century the broad guidelines laid down in the overtures, of the monitoring of conduct through detailed record keeping, were being followed. This suggests that, at least in some parishes, the efforts of the framers of the detailed guidance had been rewarded with adherence to the spirit, if not the precise letter, of their stipulations.

Examination of detailed practice in one Aberdeenshire presbytery, that of the Garioch, indicates, however, one area which was important in practice but was not laid down in detail in any of the documents we have been examining. This was that of accounting for monetary transactions, which we have seen was a cause of concern to the visitors of Kirkliston. A review of session books for the Garioch parishes suggests the early adoption of the detailed recording of monetary transactions. These can be recorded in a number of ways. In some parishes they are embedded in the text of the registers, providing a record but one which is difficult to extract. ${ }^{81}$ By contrast, the parish register of Inverurie from as early as 1716 contains a 'charge' (income) and 'discharge' (expenditure) column, ruled on each page and a running balance cast at the foot of each page. This enabled the Session to take decisions on the basis that it knew the state of its funds at any point. For example, in October 1724:

The Session considering that they distributed some money to the poor on July last, and that the balance in the Treasurer's hand is only two lib nineteen and six and that the winter is approaching when the poor will be in greater need than now, did agree to delay giving them anything till about [Martin]mas'. ${ }^{82}$

A detailed examination of records in the Garioch suggests that accounting practices became more formalised, with all the parishes moving to the practice of half-yearly

\footnotetext{
${ }^{80} \mathrm{NRS}, \mathrm{CH} 2 / 840 / 5$, Synod of Aberdeen, 13 Oct. 1790.

${ }^{81}$ For a detailed discussion based on an analysis of the records from twelve parishes, see A. Mutch, 'Systemic accountability and the governance of the Kirk: the Presbytery of Garioch in the eighteenth century, Northern Scotland 3 (2012) 45-65.

${ }^{82}$ NRS, CH2/196/2, Inverurie Kirk Session, 19 Oct. 1724.
} 
accounting as foreshadowed in the 1704 Overtures. As the century wears on this practice became a routine part of the church year, alongside the catechising of parishioners, the distribution of communion tokens and the annual communion season. It is hard to see the direct impact of the Overtures, the Form of Process or the Collections in this process, but the system of discipline clearly obtained was largely as that envisaged. An examination of the catalogue of surviving records indicates that the practice of recording monetary transactions in separate money registers, as opposed to being integrated with the records of discipline and other transactions, originated in Edinburgh in the early seventeenth century and was taken up by presbyteries in the central and southern presbyteries over the course of that century. ${ }^{83}$ Indeed, all the parishes in the Linlithgow presbytery would appear to have separate money registers by the early eighteenth century. It may have been that the framers of the Overtures and other documents simply took this level and style of accounting practice for granted and so did not feel the need to address it explicitly. Be that as it may, the importance of detailed record keeping, whatever the specific form, was clearly illustrated in the case of the Aberdeenshire parish of Monymusk in the 1790s, where the presbytery took on a reluctant heritor, pursuing its case as far as the Court of Session, and wrung concessions from him. ${ }^{84}$ This case had its genesis in the routine inspection of session records by the presbytery and their discontent at what they found there. ${ }^{85}$

\section{Conclusion}

An examination of practice at parochial level in one part of the country does suggest the effective working of a system of discipline that depended on the careful recording of a variety

\footnotetext{
${ }^{83}$ A. Mutch, 'Data mining the archives: the emergence of separate books of account in the Church of Scotland 1608-1800', Scottish Archives 18 (2012) 78-94.

${ }^{84}$ Simpson, Education, 131-6; J.M. McPherson, The Kirk's Care of the Poor, with Special Reference to the North-east of Scotland ( Aberdeen, c1941), 61; A. Mutch, 'Presbyterian governance in practice: Monymusk 1790-1825', Records of the Scottish Church History Society 42 (2013) 1-34.

${ }^{85}$ NRS, CH2/166/6, Presbytery of Garioch, 1 Dec. 1790.
} 
of transactions. ${ }^{86}$ This was set in the context of a national framework, as set out in what modern organisation scholars would term 'procedure manuals'. This can be termed a form of 'systemic accountability', that is a system of related roles and practices, where responsibilities are defined and procedures put in place to monitor whether those responsibilities have been fulfilled. This can be contrasted with religious polities such as that in the eighteenth-century Church of England, where a form of personal accountability existed, based on the character of office holders in an organisational framework which was largely determined by custom and tradition. ${ }^{87}$ Of course, in practice, what happens at local level can depart from strictures laid down by national bodies. By the same token, practices evolved at local level about which the guidance was largely silent. So, for example, we have seen that attention to processes for accounting for the poor's money was largely implicit. The source for the gradual evolution of practices for the very detailed recording of such transactions that is evident in the surviving records remains unclear. It is possible that a key figure here was the session clerk, an officer who receives relatively little attention in the guidance. Usually combining his office with that of schoolmaster, and often a divinity student hoping for ordination, such figures may have carried ideas of improvement and accounting into the parishes.

What this account does suggest, however, is the attention paid to the practical consolidation of the Revolution Settlement. ${ }^{88}$ This was broadly successful and settled into a taken for granted pattern which operated at all levels of Scottish society. While the attention of historians has understandably been on prominent national disputes such as those over

\footnotetext{
${ }^{86}$ McPherson, The Kirk's Care; J. Lindsay, The Scottish Poor Law: Its operation in the north east from 1745 to 1845 (Ilfracombe, 1975). The exception here was the western Highlands and Islands, where the arrangements envisaged by the national guidance did not take full effect until the nineteenth century.

${ }^{87}$ A. Mutch, 'Shared Protestantism' and British identity: contrasting church governance practices in eighteenthcentury Scotland and England', Social History 38 (2013) 456-476.

${ }^{88}$ Stephen, 'Defending the Revolution', 111.
} 
patronage, these taken for granted practices may have had more enduring legacies. ${ }^{89}$ Later commentators from within the church deplored the rather legalistic approach demonstrated in the documents we have reviewed. As I.M. Clark, the twentieth century minister, noted in his review of the development of discipline in the church, the 'Form of Process shows Church Discipline become more and more legalistic, outward and external, and the offender a "case" rather than a soul to be won back, if possible, to the fold of Christ. ${ }^{90}$ This legalistic cast is held by some commentators to have had a broader and enduring impact. Harvie, for example, noting the preoccupation of the church with procedures, has argued that 'this legalistic tradition has filtered ... far down into our structures of social and political behaviour' ${ }^{91}$ In a more positive vein, it could be argued that the systemic approach we have seen in the church's approach to governance mirrors a more general Scottish concern with arguing from first principles to build systems and theories. ${ }^{92}$ Certainly, a contrast with the position in the Church of England, where custom and tradition at local level produced a bewildering patchwork of organisational forms with no central blueprint tends to support such an argument. In many ways such routines become all the more important for fading into the background. ${ }^{93}$ Together with features of Scottish education during the period, taken for granted commitments to detailed record keeping and systemic forms of organising lay behind the observations of various observers about a particular Scottish competence in administration during the same period. ${ }^{94}$ This culture of organisation, based on religious practices, was then available for use not only in Scottish industrial enterprise but also more

\footnotetext{
${ }^{89}$ C.G. Brown, Religion and Society in Scotland since 1707 (Edinburgh, 1997); J. McIntosh, Church and Theology in Enlightenment Scotland: The popular party, 1740-1800 (East Linton, 1998); L. Whitley, A Great Grievance: Ecclesiastical lay patronage in Scotland until 1750 (Eugene, OR, 2013).

${ }^{90}$ I.M.Clark, A History of Church Discipline in Scotland (Aberdeen, 1929), 147.

${ }^{91}$ C. Harvie, Travelling Scot: essays on the history, politics and future of the Scots (Glendaruel, 1999), 59.

92 C. Craig, The Scots' Crisis of Confidence (Glendurael, 2011), 93.

${ }^{93}$ N.J. Demerath, P.D. Hall, T. Schmitt and R. Williams (eds) Sacred Companies: Organizational aspects of religion and religious aspects of organizations (New York, 1998).

${ }^{94}$ D. Hamilton, Scotland, the Caribbean and the Atlantic World 1750-1820 (Manchester, 2005); B.W. Higman, Plantation Jamaica 1750-1850: Capital and control in a colonial economy (Kingston, Jamaica, 2005); M. McLaren, British India and British Scotland 1780-1830: Career building, empire building, and a Scottish school of thought on Indian governance (Akron, Ohio, 2001).
} 
widely where Scottish influence was felt, notably in North America. ${ }^{95}$ Hall has noted that such 'cultures of organisation' in the nineteenth-century United States varied between social groups, where he observed that those from both Reformed Protestantism and Judaism showed a greater propensity to create voluntary associations. ${ }^{96}$ The organising skills that they had picked up in their religious activities became available resources for transfer to other activities. The links between Presbyterians in Scotland and America were particularly strong, with exchange of both spiritual and governance ideas in the eighteenth century and beyond. ${ }^{97}$ Of course, there were other factors involved, notably the impact of widespread basic education in subjects like book keeping. More work is needed to trace the impact of works such as that of Steuart of Pardovan on the development of church polity in the USA and its broader influence. In the same vein, we need to know more about how practices such as visitations operated in eighteenth-century Scotland, as opposed to assuming them from the printed guidance. As Clark pointed out, for a minister to pass all of Pardovan's questions successfully, 'should have qualified him for canonisation among the saints. The system was an encouragement to men to show up one another's faults'. ${ }^{98}$ However, the fact that such guidance was attempted and in such detail was in itself significant. It suggests a distinctively Scottish concern with system, one which is demonstrated when administrative history is placed in its broader cultural and social context.

\footnotetext{
95 T.M. Devine, To the Ends of the Earth: Scotland's global diaspora, 1750-2010 (London, 2011).

${ }^{96}$ P.D. Hall, Inventing the Nonprofit Sector and other Essays on Philanthropy, Voluntarism and Nonprofit Organizations (Baltimore, 1992), 143.

${ }^{97}$ A. Murdoch, Scotland and America c.1600-c.1800 (Basingstoke 2010), 133-7.

${ }^{98}$ Clark, History of Church Discipline, 130.
} 